\title{
Literature Review: Pengalaman Perawat dalam Melakukan Resusitasi Jantung Paru
}

\author{
Yoany Maria V.B. Aty ${ }^{1(\mathrm{CA})}$, Ignatius Tanesib ${ }^{2,}$ Rohana Mochsen ${ }^{3}$ \\ ${ }^{1(\mathrm{CA})}$ Poltekkes Kemenkes Kupang, Indonesia; vivi_aty@yahoo.co.id (Corresponding Author) \\ ${ }^{2,3}$ Poltekkes Kemenkes Kupang, Indonesia
}

\begin{abstract}
Background : Sudden death is still the main cause of death. WHO explains that most sudden deaths are caused by heart attacks. The role of nurses to prevent the death rate of cardiac arrest patients, the ability to perform cardiopulmonary resuscitation. Objective: This study aims to determine the experience of nurses in performing cardiopulmonary resuscitation. Methods: This research is a literature study by conducting a review of previous research using some relevant literature. Search articles using several search engines, including Google, Google Scholar, Research Gate, and emergency nursing journal, PUBMED journal, SINTA with the limitation of the journal publication year for the last 10 years, starting from 2011-2020. Articles used in Indonesian and English are downloaded in full text in PDF format and are free articles. Results: Based on the analysis of relevant journals, it was found that the experience of nurses in performing cardiopulmonary resuscitation is very important in efforts to save patients with cardiac and pulmonary arrest problems. Conclusion: The experience of nurses doing resuscitation is very important in an effort to save patients with respiratory and cardiac arrest problems. The experience of nurses needs to be improved through training so that nurses have the knowledge and skills to carry out resuscitation.
\end{abstract}

\section{Keywords: Nurse experience; Cardiopulmonary Resuscitation}

\begin{abstract}
ABSTRAK
Latar belakang: Kematian mendadak hingga saat ini masih menjadi penyebab utama kematian. WHO menjelaskan bahwa sebagian besar kematian mendadak disebabkan karena serangan jantung. Peran perawat untuk mencegah angka kematian pasien cardiac arrest, kemampuan untuk melakukan resusitasi jantung paru. Tujuan: Penelitian bertujuan mengetahui pengalaman perawat dalam melakukan resusitasi jantung paru. Metode: Penelitian ini merupakan sebuah studi literatur dengan melakukan kajian terhadap penelitian terdahulu menggunakan beberapa literatur yang relevan. Penelusuran artikel menggunakan beberapa searchengine, diantaranya Google, Google Scholar, Research Gate, dan emergency nursing journal, PUBMED journal, SINTA dengan batasan tahun publikasi jurnal 10 tahun terakhir yaitu mulai dari tahun 2011-2020. Artikel yang digunakan berbahasa Indonesia dan bahasa Inggris yang didownload fulltext dengan format PDF dan merupakan artikel tidak berbayar. Hasil: Berdasarkan hasil analisis terhadap jurnal yang relevan didapatkan hasil bahwa pengalaman perawat dalam melakukan resusitasi jantung paru sangat penting dalam upaya keselamatan pasien dengan masalah henti jantung dan henti paru. Kesimpulan: Pengalaman perawat melakukan resusitasi sangat penting dalam upaya menyelamatkan pasien dengan masalah henti napas dan henti jantung. Pengalaman perawat perlu ditingkatkan melalui pelatihan - pelatihan sehingga perawat mempunyai pengetahuan dan keterampilan dalam melakukan resusitasi.
\end{abstract}

Kata Kunci : Pengalaman perawat, Resusitasi Jantung Paru

\section{PENDAHULUAN}

Serangan jantung merupakan penyebab utama kematian mendadak dan penyebab utamanya yakni penyakit jantung koroner. Setiap tahunnya lebih dari 36 juta orang meninggal akibat penyakit 
kardiovaskuler (Oktavianus, 2012). Penelitian di Amerika Serikat oleh Chan et al tahun 2014,menunjukkan sebanyak 70\% serangan jantung di luar rumah sakit atau out-of-hospital cardiac arrests (OHCA) terjadi di rumah. Data statistik World Health Organization (WHO) pada tahun 2016 menjelaskan bahwa penyakit jantung koroner merupakan penyebab kematian utama di dunia. Terdapat 7,4 juta $(42,3 \%)$ kematian terjadi disebabkan oleh penyakit jantung koroner. Penyakit jantung koroner merupakan salah satu faktor resiko terjadinya kasus henti jantung. Data Riset Kesehatan Dasar (Riskesdas) tahun 2018 menunjukkan bahwa di Indonesia prevalensi penyakit jantung koroner sebanyak $1,5 \%$.

Resusitasi jantung paru merupakan tindakan pertolongan pertama untuk bisa memberikan sirkulasi ke organ vital tubuh. Dengan tindakan ini dapat menolong pasien yang mengalami henti napas atau henti jantung agar tetap hidup. Tindakan ini telah banyak mengalami perubahan dan perkembangan seiring dengan kemajuan teknologi. Penatalaksanaan RJP di Indonesia berpedoman pada AHA ( American Heart Association) 2015 Guidelines for Cardiopulmonary Resucitation and Emergency Cardiovascular Care. Urutan untuk melakukan RJP dimulai kompresi dada dilanjutkan dengan memberikan napas buatan dengan perbandingan 30:2. Hal ini berbeda ketika memberikan RJP kepada korban tenggelam, yang mana tetap membebaskan jalan napas, memberikan napas buatan lalu kompresi dada.

Perawat menjadi satu tokoh penting dalam mencegah angka kematian pasien cardiac arrest, karena selalu berada dekat dengan pasien. Banyak faktor yang menyebabkab keberhasilan dalam melakukan resusitasi jantung paru. Pratondo (2012), menyebutkan keberhasilan RJP disebabkan karena kompetensi yang dimiliki oleh perawat, perawat memiliki pengalaman yang baik, telah mendapat pelatihan, BLS dan ACLS. Keberhasilan melakukan RJP sangat dipengaruhi oleh kemampuan perawat dalam mengidentifikasi dan menganalisa kondisi pasien yang mengalami cardiac arrest. Ketika perawat mampu mengenali kondisi pasien sedini mungkin, maka pemberian resusitasi juga dilakukan secepatknya. Hasil riset yang dilakukan Aty tahun 2019 menjelaskan bahwa ada hubungan pengalaman dengan keberhasilan melakukan resusitasi jantung paru. Pengalaman ini didapatkan dari pelatihan dan sering melakukan RJP, sudah bekerja lama di unit gawat darurat, ICU dan ICCU. Berdasarkan beberapa uraian diatas maka perlu dilakukan literature review tentang pengalaman perawat dalam melakukan resusitasi jantung paru.

\section{METODE}

Dalam penelitian ini, merupakan literatur review. Pengumpulan data menggunakan kajian kepustakaan terhadap penelitian sebelumnya Studi kepustakaan memanfaatkan sumber yang ada untuk memperoleh data penelitian. Metode yang di dipakai melalui pendekatan sistematis untuk melakukan analisa data secara sederhana. Artikel desain penelitian kualitatif dengan studi fenomenologi. Penelusuran hasil penelitian dari artikel yang menggunakan bahasa Inggris dan indonesia. Artikel yang digunakan berfokus pada original empirical research atau artikel penelitian dengan data berasal hari hasil wawancara adanya abstrak, pendahuluan, metode, hasil, serta diskusi.

Kriteria inklusi untuk menentukan artikel literature review, adalah: 1) desain penelitian kualitatif, 2) Artikel asli dari sumber utama (primary source). 3) terbit tahun 2013 sampai tahun 2018, 4) full text 
berbahasa Inggris, dan bahasa Indonesia 5) partisipan dalam artikel adalah perawat yang telah melakukan resusitasi jantung paru. Kriteria eksklusi adalah: 1) Artikel diluar pengalaman perawat dalam melakukan resusitasi jantung paru, 2) Artikel diterbitkan diatas 10 tahun terakhir/ sebelum tahun 2013, 3) Artikel hanya memuat bagian abstrak atau sebagian part of text. Strategi Penelusuran literatur dilakukan dengan menggunakan jurnal yang diperoleh dari database berupa google shcolar, research gate, dan emergency nursing journal, PUBMEd journal, SINTA sebanyak 65 jurnal. Setelah dibaca, dipilih dan dipilah data ditetapkan 4 artikel yang akan direview.

\section{HASIL}

Table 1. Hasil Kajian Literatur

\begin{tabular}{|c|c|c|c|c|c|}
\hline $\begin{array}{l}\mathbf{N} \\
\mathbf{0}\end{array}$ & $\begin{array}{c}\text { Pengarang dan } \\
\text { Tahun }\end{array}$ & Tujuan & $\begin{array}{c}\text { Subyek } \\
\text { penelitian }\end{array}$ & Hasil & Rekomendasi \\
\hline 1 & $\begin{array}{lr}\text { Mulyadi } & \text { dan } \\
\text { Maykel } & \text { Kiling } \\
(2018) & \end{array}$ & $\begin{array}{l}\text { mengetahui } \\
\text { pengalaman } \\
\text { perawat dalam } \\
\text { penanganan } \\
\text { cardiac arrest di } \\
\text { Instalasi Gawat } \\
\text { Darurat RSUP } \\
\text { Prof Dr R D } \\
\text { Kandou Manado }\end{array}$ & $\begin{array}{l}\text { Partisipan } \\
\text { perawat IGD } \\
\text { yang pernah } \\
\text { menangani } \\
\text { kasus cardiac } \\
\text { arrest } \\
\text { sebanyak } 4 \\
\text { partisipan. }\end{array}$ & $\begin{array}{l}\text { Dari penelitian didapatkan hasil : } \\
\text { 1. Pengetahuan perawat tentang cardiac } \\
\text { arrest. } \\
\text { Hasil penelitian menyatakan bahwa } \\
\text { cardiac arrest adalah suatu kondisi } \\
\text { dimana, tidak terdapatnya tanda - } \\
\text { tanda kehidupan seperti tidak adanya } \\
\text { nadi atau denyut jantung, jantung } \\
\text { kehilangan fungsinya, dan fungsi } \\
\text { jantung mendadak berhenti yang } \\
\text { dapat dilihat melalui penilaian secara } \\
\text { fisik dan penilaian secara fisiologis. } \\
\text { 2. Tindakan Perawat dalam penanganan } \\
\text { Cardiac Arrest } \\
\text { Hasil Penelitian menyatakan bahwa, } \\
\text { penanganan cardiac arrest dimulai } \\
\text { dengan mengecek respon pasien, cek } \\
\text { nadi dan nafas, melakukan pijat } \\
\text { jantung dan paru } 30 \text { : 2, kemudian } \\
\text { memasang monitor untuk evaluasi } \\
\text { pasien. } \\
\text { 3. Faktor pendukung perawat dalam } \\
\text { penanganan cardiac arrest. } \\
\text { Hasil penelitian menyatakan bahwa, } \\
\text { faktor pendukung dalam penanganan } \\
\text { cardiac arrest tergantung dari, kondisi } \\
\text { dan keadaan umum pasien, skill dari } \\
\text { petugas, respon time petugas, } \\
\text { ketersediaan alat-alat di ruangan, dan } \\
\text { kesiapan dari tim medis. } \\
\text { 4. Faktor Penghambat perawat dalam } \\
\text { penanganan cardiac arrest } \\
\text { Hasil penelitian menyatakan bahwa } \\
\text { hambatan sarana dan prasarana } \\
\text { meliputi keterbatasan alat-alat, obat- } \\
\text { oabatan emergency, jauhnya } \\
\text { jangkauan pengambilan obat } \\
\text { emergensi, banyaknya pengunjung } \\
\text { dan keluarga dalam ruangan, } \\
\text { penolakan melakukan bantuan hidup } \\
\text { dasar dari keluarga, petugas dan } \\
\text { pasien tidak sebanding, cara atau } \\
\text { posisi dalam melakukan bantuan } \\
\text { hidup dasar tidak sesuai. }\end{array}$ & $\begin{array}{l}\text { Perlu adanya } \\
\text { kesediaan } \\
\text { sarana dan } \\
\text { prasarana yang } \\
\text { memadai serta } \\
\text { SDM kesehatan } \\
\text { yang memiliki } \\
\text { tingkat } \\
\text { pengetahuan } \\
\text { dan } \\
\text { keterampilan } \\
\text { yang baik dalam } \\
\text { melakukan RJP. }\end{array}$ \\
\hline
\end{tabular}




\begin{tabular}{|c|c|c|c|c|c|}
\hline $\begin{array}{l}\mathbf{N} \\
\mathbf{0}\end{array}$ & $\begin{array}{c}\text { Pengarang dan } \\
\text { Tahun }\end{array}$ & Tujuan & $\begin{array}{c}\text { Subyek } \\
\text { penelitian }\end{array}$ & Hasil & Rekomendasi \\
\hline 2 & $\begin{array}{l}\text { Risna Yekti } \\
\text { Mumpuni, } \\
\text { Indah Winarni } \\
\text { dan Ali Haedar } \\
\text { (2016) }\end{array}$ & $\begin{array}{l}\text { Untuk memaknai } \\
\text { pengalaman } \\
\text { perawat } \\
\text { Puskesmas dalam } \\
\text { penatalaksanaan } \\
\text { OHCA. }\end{array}$ & $\begin{array}{l}\text { Sebanyak } 4 \\
\text { orang } \\
\text { disesuaikan } \\
\text { dengan tujuan } \\
\text { penelitian } \\
\text { dengan } \\
\text { kriteria } \\
\text { memiliki } \\
\text { pengalaman } \\
\text { dalam } \\
\text { melakukan } \\
\text { penatalaksana } \\
\text { an OHCA, } \\
\text { pendidikan } \\
\text { minimal DIII, } \\
\text { memiliki } \\
\text { sertifikat BLS } \\
\text { dan atau } \\
\text { ACLS }\end{array}$ & 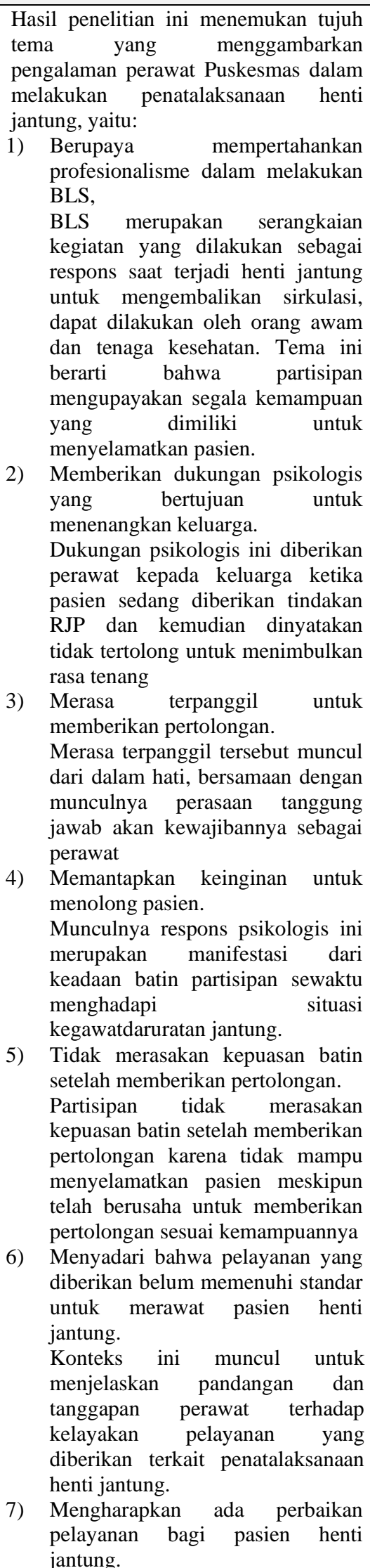 & $\begin{array}{l}\text { Diperlukan } \\
\text { adanya } \\
\text { peningkatan } \\
\text { kompetensi } \\
\text { perawat yang } \\
\text { bertugas di } \\
\text { UGD } \\
\text { Puskesmas } \\
\text { melalui } \\
\text { pendidikan } \\
\text { bantuan hidup } \\
\text { lanjut (ACLS) } \\
\text { dan pelatihan } \\
\text { khusus } \\
\text { prehospital yang } \\
\text { berkesinambung } \\
\text { an untuk } \\
\text { memperbaharui } \\
\text { ilmu pu } \\
\text { pengetahuan } \\
\text { dan keterampilan } \\
\text { klinis khususnya } \\
\text { dalam bidang } \\
\text { memberikan } \\
\text { pertolongan } \\
\text { bagi pasien } \\
\text { henti jantung } \\
\text { pada setting } \\
\text { prehospital. }\end{array}$ \\
\hline
\end{tabular}




\begin{tabular}{|c|c|c|c|c|c|}
\hline $\begin{array}{l}\mathbf{N} \\
\mathbf{0}\end{array}$ & $\begin{array}{c}\text { Pengarang dan } \\
\text { Tahun }\end{array}$ & Tujuan & $\begin{array}{c}\text { Subyek } \\
\text { penelitian }\end{array}$ & Hasil & Rekomendasi \\
\hline & & & & $\begin{array}{l}\text { Partisipan mengharapkan ada } \\
\text { perbaikan pelayanan bagi pasien } \\
\text { henti jantung yang diberikan oleh } \\
\text { berbagai pihak untuk } \\
\text { meningkatkan kualitas pelayanan } \\
\text { terhadap pasien. }\end{array}$ & \\
\hline 3 & $\begin{array}{ll}\text { Mi-run Lee, } \\
\text { Chiyoung } \\
\text { Cha(2016) }\end{array}$ & $\begin{array}{l}\text { Mengeksplorasi } \\
\text { pengalaman } \\
\text { perawat } \\
\text { melakukan CPR }\end{array}$ & $\begin{array}{l}\text { Partisipan } \\
\text { pada } \\
\text { penelitian ini } \\
\text { bejumlah } 17 \\
\text { perawat }\end{array}$ & $\begin{array}{l}\text { Penelitian ini mendapatkan hasil : } \\
\text { Tekanan dari urgensi CPR. } \\
\text { Ketika peserta mengingat situasi } \\
\text { CPR, mereka akan menjadi tegang } \\
\text { karena situasi mendesak yang } \\
\text { membutuhkan CPR. Peserta } \\
\text { merasakan jantung mereka } \\
\text { berdebar-debar karena stres } \\
\text { melakukan CPR pada pasien } \\
\text { dengan sedikit informasi dan } \\
\text { menyimpang dari perawatan rutin. } \\
\text { Sebagian besar pasien dengan henti } \\
\text { jantung adalah pasien yang datang } \\
\text { ke UGD dari ambulan. Peserta } \\
\text { khawatir tentang melakukan CPR } \\
\text { tanpa informasi sebelumnya, } \\
\text { seperti penyebab pasti serangan } \\
\text { jantung dan penyakit yang } \\
\text { mendasarinya. Karena peserta } \\
\text { memiliki ketakutansaat mengetahui } \\
\text { informasi tentang pasien, mereka } \\
\text { khawatir menggunakan obat- } \\
\text { obatan atau melakukan prosedur. } \\
\text { Mereka cemas karena tidak dapat } \\
\text { menunjukkan kemampuan mereka } \\
\text { atau ada sesuatu yang salah karena } \\
\text { mereka tidak tahu obat atau } \\
\text { prosedur baru. } \\
\text { Perasaan marah terhadap anggota } \\
\text { CPR selama proses CPR. } \\
\text { Perasaan tegang selama proses } \\
\text { CPR dalam menangani hidup dan } \\
\text { mati pasien, para peserta CPR } \\
\text { seringkali menjadi sensitif dan } \\
\text { emosional terhadap anggota tim } \\
\text { CPR lainnya. Selama proses CPR } \\
\text { berlangsung anggota tim harus } \\
\text { berpartisipasi secara efektif dalam } \\
\text { menjalankan perintah yang dapat } \\
\text { berubah sewaktu- waktu } \\
\text { berdasarkan keadaan pasien. } \\
\text { Dalam proses CPR anggota tim } \\
\text { seringkali merasa terluka karena } \\
\text { nada kasar yang dikeluarkan yang } \\
\text { membuat terluka secara pribadi. } \\
\text { Peserta juga merasa tidak nyaman } \\
\text { ketika mereka harus melakukan } \\
\text { RJP dengan perawat dengan } \\
\text { pengalaman RJP terbatas dan tidak } \\
\text { mampu melakukan perannya } \\
\text { dengan baik, hal ini yang membuat } \\
\text { ketidakharmonisan dalam anggota } \\
\text { tim dan dapat menyebabkan hasil } \\
\text { yang kurang baik, }\end{array}$ & $\begin{array}{l}\text { Perlu adanya } \\
\text { pelatihan } \\
\text { tambahan } \\
\text { pelaksanaan } \\
\text { CPR dan } \\
\text { rehabilitasi } \\
\text { psikologis. }\end{array}$ \\
\hline
\end{tabular}




\begin{tabular}{|c|c|c|c|c|c|}
\hline $\begin{array}{l}\mathbf{N} \\
\mathbf{0}\end{array}$ & $\begin{array}{c}\text { Pengarang dan } \\
\text { Tahun }\end{array}$ & Tujuan & $\begin{array}{c}\text { Subyek } \\
\text { penelitian }\end{array}$ & Hasil & Rekomendasi \\
\hline & & & & $\begin{array}{l}\text { Menjaga konflik psikologi dari } \\
\text { perawatan pasien RJP untuk diri } \\
\text { sendiri. } \\
\text { Dalam melakukan CPR, para } \\
\text { peserta sering mengalami konflik } \\
\text { psikologis untuk berbagai alasan. } \\
\text { Namun, mereka ragu untuk } \\
\text { mengungkapkan masalah internal } \\
\text { mereka dan menyimpan } \\
\text { masalahnya sendiri. } \\
\text { 4) } \\
\text { kebasaan bangga } \\
\text { Peserta mengan } \\
\text { ketakutan saat melakukan CPR } \\
\text { tetapi akan merasa bangga ketika } \\
\text { proses RJP berhasil dan pasien } \\
\text { dapat terselamatkan. }\end{array}$ & \\
\hline 4 & $\begin{array}{l}\text { Martin } \\
\text { Salzmann- } \\
\text { Erikson RN, } \\
\text { PhD (2015) }\end{array}$ & $\begin{array}{l}\text { Untuk } \\
\text { menggambarkan } \\
\text { pengalaman } \\
\text { perawat dalam } \\
\text { melakukan RJP di } \\
\text { unit perawatan } \\
\text { intensif. }\end{array}$ & $\begin{array}{l}\text { Delapan } \\
\text { perawat } \\
\text { berpartisipasi } \\
\text { dalam } \\
\text { penelitian ini. }\end{array}$ & $\begin{array}{l}\text { Hasil menggambarkan pengalaman } \\
\text { informan CPR menurut tiga kategori: } \\
\text { 1) Pra-CPR } \\
\text { Secara umum, pelatihan RJP } \\
\text { adalah kegiatan penting. Para } \\
\text { informan percaya bahwa pelatihan } \\
\text { yang cukup akan berpengaruh } \\
\text { pada kesiapan dalam mengahadapi } \\
\text { proses CPR sewaktu- waktu. } \\
\text { Selain itu, pelatihan juga berfungsi } \\
\text { untuk mempersiapkan diri dan } \\
\text { dapat menurunkan tingkat stress } \\
\text { dalam situasi nyata. } \\
\text { 2) Selama CPR. } \\
\text { Melakukan CPR, kontrol dan } \\
\text { pengalaman ketertiban sangat } \\
\text { penting dalam proses keberhasilan } \\
\text { CPR. } \\
\text { Pasca-CPR } \\
\text { Para informan mengatakan bahwa } \\
\text { perlunya diskusi khusus anggota } \\
\text { tim CPR setelah proses CPR } \\
\text { berlangsung untuk membicarakan } \\
\text { tentang peristiwa- peristiwa yang } \\
\text { terjadi agar tidak menjadi beban } \\
\text { tersendiri. }\end{array}$ & $\begin{array}{l}\text { Perlu adanya } \\
\text { Pembekalan } \\
\text { tentang acara } \\
\text { yang sulit itu } \\
\text { menstimulasi } \\
\text { tim kerja. } \\
\text { Pembekalan } \\
\text { juga penting } \\
\text { bagi staf untuk } \\
\text { menangani } \\
\text { secara efektif } \\
\text { perasaan yang } \\
\text { belum diproses } \\
\text { sebelum mereka } \\
\text { pulang }\end{array}$ \\
\hline
\end{tabular}

Hasil penelusuran literatur dibaca berulang-ulang untuk mendapatkan makna penting dari setiap penelitian yang berkaitan dengan studi tentang pengalaman perawat dalam melakukan resusitasi jantung paru di unit gawat darurat.

Tabel 2. Hasil Analisa Tematik

\begin{tabular}{|l|l|l|}
\hline No & \multicolumn{1}{|c|}{ Pernyataan Penting } & Makna rumusan \\
\hline 1. & $\begin{array}{l}\text { Pentingnya memperhatikan faktor pendukung dan faktor } \\
\text { penghambat dalam melakukan RJP }\end{array}$ & $\begin{array}{l}\text { Sumber daya manusia, sarana } \\
\text { dan prasarana }\end{array}$ \\
\hline
\end{tabular}




\begin{tabular}{|l|l|l|}
\hline No & \multicolumn{1}{|c|}{ Pernyataan Penting } & \multicolumn{1}{|c|}{ Makna rumusan } \\
\hline 2. & $\begin{array}{l}\text { Pentingnya keterlibatan biopsikososial dari seorang perawat } \\
\text { dalam melakukan RJP }\end{array}$ & Kesiapan biopsikososial \\
\hline 3. & $\begin{array}{l}\text { Pentingnya memperhatikan hambatan dan dukungan dalam } \\
\text { melakukan RJP pada Neonatus }\end{array}$ & $\begin{array}{l}\text { Sumber daya manusia, sarana } \\
\text { dan prasarana }\end{array}$ \\
\hline 4. & $\begin{array}{l}\text { Pentingnya dukungan psikologis dan peningkatan sumber daya } \\
\text { manusia. }\end{array}$ & Kesiapan biopsikososial \\
\hline 5. & $\begin{array}{l}\text { Pentingnya dukungan psikologis untuk perawat dalam } \\
\text { melakukan RJP. }\end{array}$ & Kesiapan biopsikososial \\
\hline 6. & Pentingnya peningkatan sumber daya manusia. & Sumber daya manusia. \\
\hline
\end{tabular}

Tema yang ditetapkan dari makna rumusan pada enam jurnal mencakup: kesiapan biopsikososial sebanyak 3 jurnal dan 3 jurnal lainnya membahas tentang sumber daya manusia dan dukungan sarana prasarana; dengan demikian peneliti menetapkan 2 tema penting yaitu: pentingnya faktor pendukung berupa sumber daya manusia dan sarana prasarana dalam mendukung keberhasilan RJP dan pentingnya kesiapan biopsikososial dari seorang perawat dalam melakukan RJP.

\section{PEMBAHASAN}

Dalam penelitian ini terdapat dua tema penting yaitu kesiapan biopsikososial dan sumber daya manusia dan dukungan sarana prasarana dalam melakukan RJP pada pasien dengan cardiac arrest. Pengalaman perawat sangat berhubungan erat dengan kesiapan biopsikososial perawat dan sarana untuk bisa mendukung keberhasilan dalam melakukan resusitasi. Perawat perlu siap untuk bisa menghadapi situasi kegawatan yang dialami oleh pasien ini tentunya membutuhkan kemampuan untuk berfikir kritis, menilai situasi, ketrampilan teknis yang memadai, dan berkomunikasi yang baik. Kesiapan perawat dalam aspek biopsikososial ini sangat dipengaruhi oleh beberapa faktor, yaitu pengetahuan yang cukup dari perawat tentang penanganan situasi kegawatan, pengalaman yang memadai, protokol yang jelas, sarana yang baik, dan pelatihan atau training penanganan situasi kegawatan yang diikuti (Wolff, dkk, 2010).

\section{Kesiapan biopsikososial perawat}

Kesiapan biopsikologis merupakan kondisi seseorang yang siap memberikan respon atau jawaban terhadap suatu situasi tertentu (Slameto,2010). Holm (2016) menjelaskan bahwa kesiapan perawat adalah kemampuan untuk bisa beradaptasi dalam berbagai domain pengasuhan, seperti memberikan perawatan praktis dan dukungan emosional, serta mengelola stres yang berkaitan dengan perawatan. Kesiapan untuk mengasuh memiliki aspek praktis dan emosional dan tindakan yang dilakukan berdasarkan kemampuan kognitif yang dimiliki dan bisa mengatasi emosi dan stress saat menghadapi pasien yang mengalami kondisi gawat darurat, sehingga secara logis bisa memutuskan tindakan yang akan dilakukan untuk bisa menyelamatkan pasien. 
Risna Yekti Mumpuni (2017) menjelaskan dukungan psikologis diberikan perawat kepada keluarga saat pasien sedang diberikan tindakan RJP dan kemudian dinyatakan tidak tertolong untuk menimbulkan rasa tenang. Perasaan terpanggil tersebut muncul dari dalam hati, bersamaan dengan munculnya perasaan tanggung jawab akan kewajibannya sebagai perawat. Keinginan untuk menolong pasien merupakan tindakan spontanitas yang dilakukan perawat saat menghadapi situasi kegawatdaruratan jantung. Partisipan tidak merasakan kepuasan batin setelah memberikan pertolongan karena tidak mampu menyelamatkan pasien meskipun telah berusaha untuk memberikan pertolongan sesuai kemampuannya. Partisipan juga mengharapkan ada perbaikan pelayanan bagi pasien henti jantung yang diberikan oleh berbagai pihak untuk meningkatkan kualitas pelayanan terhadap pasien.

Mi-run Lee, Chiyoung Cha (2018) menjelaskan bahwa saat perawat melakukan resusitasi, seringkali perawat mengalami tekanan psikologis seperti cemas dan tegang akan ketepatan melakukan tindakan dan perasaan marah dengan anggota tim dalam melakukan resusitasi jantung paru. Martin Salzmann-Erikson (2015) menyebutkan pelatihan tentang RJP juga dikaitkan dengan situasi persiapan diri dalam menurunkan tingkat stress dalam situasi nyata.

Sering kali perawat mengalami tekanan psikologis seperti marah, cemas dan tegang akan sangat mempengaruhi ketepatan melakukan tindakan. Pelatihan akan meningkatkan kesiapan diri dari seorang perawat dalam melakukan RJP agar mengurangi dampak atau tekanan psikologis yang ada.

\section{Sumber daya manusia, sarana dan prasarana}

Kesiapan perawat dalam menghadapi situasi kegawatan adalah kemampuan untuk berfikir kritis, kemampuan untuk menilai kondisi pasien yang mengalami henti hapas dan jantung. Perawat perlu memiliki ketrampilan teknis yang memadai, dan kemampuan untuk berkomunikasi. Pengetahuan berpengaruh pada keterampilan perawat dalam melaksanakan tugasnya.. Sarana prasarana yang cukup merupakan segala sesuatu yang dapat memudahkan dan memperlancar tindakan perawat. Pelatihan membantu perawat untuk menguasai keterampilan dan kemampuan atau kompetensi yang spesifik untuk berhasil dalam pekerjaannya. Faktor pendukung dalam penanganan cardiac arrest tergantung dari kondisi dan keadaan umum pasien, skill dari petugas, pengetahuan, pengalaman, respon time petugas, ketersediaan alat- alat di ruangan, dan kesiapan dari tim medis.

\section{KESIMPULAN}

Berdasarkan hasil penelitian yang ada, pengalaman dalam melakukan resusitasi jantung paru ialah kemampuan seorang perawat dalam menilai suatu kondisi dimana, tidak terdapatnya tanda - tanda kehidupan seperti tidak adanya nadi atau denyut jantung, jantung kehilangan fungsinya, dan fungsi jantung mendadak berhenti yang dapat dilihat melalui penilaian secara fisik dan penilaian secara fisiologis. Pengetahuan dan ketarampilan perawat sangat penting dalam menilai kondisi pasien sebelum dilakukan tindakan resusitasi. Faktor pendukung dalam melakukan resusitasi terhadap penanganan cardiac arrest tergantung dari, kondisi dan keadaan umum pasien, skill dari petugas, respon time petugas, ketersediaan alat-alat di ruangan, dan kesiapan dari tim medis. Dalam memberikan dukungan emosional terhadap keluarga dan pasien dengan cardiac aresst seorang perawat harus memberikan rasa empati, 
cinta, kejujuran dan selalu memberikan motivasi. Dukungan perawat diwujudkan dalam bentuk sikap, adanya kepercayaan, perhatian dan menjadi pendengar yang baik bagi pasien.

Perawat perlu meningkatkan pengalaman, pengetahuan, keterampilan serta mental yang cukup dengan sering melakukan pelatihan bls atau btcl secara rutin minimal setiap bulan. Terlibat dalam workshop, dan FGD dengan menggunakan berbagai media, seperti flipchart, poster, gambar grafik, modul tentang resusitasi jantung paruagar setiap tindakan yang dilakukan dapat berjalan dengan baik.

\section{DAFTAR PUSTAKA}

American Heart Assiciation. (2015) "Fokus Utama Pembaruan Pedoman AHA 2015 untuk CPR dan ECC". Jakarta: AHA

Amestiasih, T. (2015). Studi Fenomenologi: Pengalaman Perawat Dalam Merawat Pasien Terminal Dengan Do Not Resuscitate (Dnr) Di Ruang Icu Rsup Dr. Soeradji Tirtonegoro Klaten (Doctoral dissertation, Universitas Brawijaya).

Arismunandar, A., Suharyono, S., \& Aryani, A. (2019). Hubungan tingkat kecemasan pasien dengan tindakan pencabutan gigi di poli gigi puskesmas (Doctoral dissertation, Poltekkes Kemenkes Yogyakarta).

Assarroudi, A., Nabavi, F. H., Ebadi, A., \& Esmaily, H. (2017). Do-not-resuscitate order: the experiences of Iranian cardiopulmonary resuscitation team members. Indian journal of palliative care, 23(1), 88.

Brizzi, M., Abul-Kasim, K., Jalakas, M., Selariu, E., Pessah-Rasmussen, H., \& Zia, E. (2012). Early do-not-resuscitate orders in intracerebral haemorrhage; frequency and predictive value for death and functional outcome. A retrospective cohort study. Scandinavian journal of trauma, resuscitation and emergency medicine, 20(1), 36.

Carpenito, L. J. (1997). Development of nursing diagnosis. Nursing diagnosis: application to clinical practice, 7, 3-11.

Cole, F. L., Slocumb, E. M., \& Mastey, J. M. (2001). A measure of critical care nurses' post-code stress. Journal of Advanced Nursing, 34(3), 281-288

Couper, K., \& Perkins, G. D. (2013). Debriefing after resuscitation. Current opinion in critical care, 19(3), 188-194.

Darwati, L. E., Winarni, I., \& Haedar, A. (2015). Studi Fenomenologi: Pengalaman Perawat Dalam Melaksanakan Asuhan Keperawatan Pada Pasien Henti Jantung Di Salah Satu Igd Rumah Sakit Tipe a Di Jawa Timur. Medika Respati: Jurnal Ilmiah Kesehatan, 10(4).

Drotske, J. S., \& De Villiers, P. J. T. (2007). Resuscitation debriefing for nurses at the Accident and Emergency Unit of St Dominique's Hospital in East London (South Africa). South African Family Practice, 49(10), 17-17d.

Glaa, B., \& Chick, S. (2011). Trained nurse location model for in-hospital cardiac arrest survival (Vol. 84). Faculty and research working paper.

Ismiroja, R., Mulyadi, N., \& Kiling, M. (2018). Pengalaman Perawat Dalam Penanganan Cardiac Arrest Di Instalasi Gawat Darurat Rsup Prof. Dr. Rd Kandou Manado. Jurnal Keperawatan, 6(2). 
Kozamani A, Kapadochos T \& Kadda O (2012) Faktor-faktor yang mempengaruhi sikap staf perawat terhadap memulai CPR dan dalam menggunakan defibrillator eksternal otomatis ketika berada di luar rumah sakit. Jurnal Ilmu Kesehatan 6 (1), 88-101.

Kumalasari, M. D., Achwandi, M., \& Yuniarti, E. V. (2019). Pengetahuan Perawat Dalam Melakukan Resusitasi Jantung Paru (RJP).

Lee, M. R., \& Cha, C. (2018). Emergency department nurses' experience of performing CPR in South Korea. International emergency nursing, 38, 29-33.

Meissner, T. M., Kloppe, C., \& Hanefeld, C. (2012). Basic life support skills of high school students before and after cardiopulmonary resuscitation training: a longitudinal investigation. Scandinavian journal of trauma, resuscitation and emergency medicine, 20(1), 31.

Mekka, R. R., Ratnawati, R., \& Rachmawati, S. D. (2016). Studi fenomenologi: pengalaman perawat terkait ketidakberhasilan resusitasi pada neonatal dengan asfiksia di ruang neonatus rsud dr. R. Soedjono selong lombok timur. Jurnal Ilmu Keperawatan: Journal of Nursing Science.

Mumpuni, R. Y., Winarni, I., \& Haedar, A. (2017). Pengalaman Perawat Puskesmas Kota Malang Dalam Penatalaksanaan Henti Jantung (Out-of-Hospital Cardiac Arrest). Medica Majapahit.

Pedersen, H. K., Gudmundsdottir, V., Nielsen, H. B., Hyotylainen, T., Nielsen, T., Jensen, B. A., ... \& Le Chatelier, E. (2016). Human gut microbes impact host serum metabolome and insulin sensitivity. Nature, 535(7612), 376-381.

Potter, P., \& Perry, A. G. (2010). Fundamental Of Nursing: Consep, Proses and Practice. Edisi I, 3.

Pratondo, \& Oktavianus. (2012) "Presepsi Perawat Tetang Faktor-Faktor yang Mempegaruhi Keberhasilan Resusitasi Jantung Paru di UPJ RSUP Dr. Kariadi Semarang” . Jurnal Kesehatan Kusuma Husada

Sjöberg, F., Schönning, E., \& Salzmann-Erikson, M. (2015). Nurses' experiences of performing cardiopulmonary resuscitation in intensive care units: a qualitative study. Journal of clinical nursing,

Wolf, L.A., Altair, M.D, et al. (2015). Exploring the management of death: Emergency nurses' perceptions of challenges and facilitators in the provision of end-of-life care in the emergency department. Journal of Emergency Nursing, 41 (5), e23-e33. 